\title{
A Study on the Effectiveness of Context Theory-based College English Reading
}

\author{
Yuewei Zhang \\ College of Foreign Languages, Bohai University, Jinzhou, 121013, China \\ zhangyueweiy@163.com
}

Keywords: context theory; college English reading; effectiveness

\begin{abstract}
This research project aims to explore new approaches of English reading teaching by the effective use of context theories in order to improve college students' English reading abilities. The experimental study was undertaken in a university in the Northeast of China, from March to June 2015. Fifty-eight sophomore students in experimental class were taught by using the context-based reading teaching method, while fifty-seven sophomore students in control class were taught by the traditional teaching method. Research instruments in this study included questionnaires, tests and interviews. All the data were analyzed using qualitative and quantitative techniques. The experiment shows that English reading teaching by using context theory can improve students' reading comprehension ability, which can also alter students' attitude towards reading. Therefore, applying context theory to college English reading teaching is feasible and effective. Finally, it is expected that college English teachers can be enlightened by the result of the study in terms of these English reading teaching methods, which can contributes to pedagogy in terms of teaching method.
\end{abstract}

\section{Introduction}

It is recognized that English reading is the most important part of English learning. Reading is also considered as an active, fluent process in which both reader and reading materials subsume building meaning (Anderson, 2012) [1]. Nowadays many college English teachers use traditional reading teaching method. Additionally, teachers and students know little knowledge relevant to context. Therefore, in order to learn English reading well, teachers and students should study more knowledge about context and apply it to reading skillfully. As a result, finding out an effective reading teaching method has become an urgent issue for English teachers.

Grabe and Stoller (2013) [2] states that successful reading connects relevant text content to one's own background knowledge of the subject. This paper aims to apply context theory to English reading teaching and help students improve their reading skill. This research attempts to find out whether reading teaching under the guidance of context theory can improve students' reading achievement. The paper not only complements students' knowledge of the context theory, but also provides a feasible and practical approach to college English reading teaching for teachers. It is hoped that the paper will play a theoretical and pedagogical role in the research field. Theoretically, college students will be taught some theoretical imports about context. Pedagogically, a context-based college English teaching mode will be formulated.

The present paper consists of 5 parts. Part One is introduction, which includes the research background, significance and layout of the paper. Part Two is the theoretical framework, the concept of context, current research on context and its application in English reading instruction. Part Three subsumes research methodology and research instruments adopted in this study. Part Four involves the results and discussions. Part Five is the conclusion. 


\section{Context Theory and its Application in Reading Teaching}

Context is a crucial concept in pedagogy. Based on Halliday (2005) [3], context is a theoretical category, which can make language explained from different aspects. He argues that context includes two parts: one is linguistic context, the other is non-linguistic context. Lyons (1995) [4] indicates that elements comprising context are abstracted from the concrete, and these elements with an effect on the source of language activities determines language appropriateness and utterance meaning. Brown and Yule (2008) [5] argue that context relates to possible world, time, place, audience, indicated object and precious discourse.

The conception of context theory has an important position in many branches of linguistics, especially in the research of pragmatics. Moreover, it is regarded as a symbol which can discriminate semantics and pragmatics. In short, although each linguist and scholar has different understandings about context, they all agree that context plays an essential role in understanding a text. In a narrow sense, context refers to co-text; in a broad sense, context relates to the society, culture and background. Context is the environment in which language is used correctly.

Functions of context play a pretty important role in understanding the meaning of words or sentences. Context has many functions, while the most crucial and basic functions are semantic co-occurrence, disambiguation, selective restrictions and interpretation.

According to the needs of current reading teaching, many linguists have paid much attention to the studies of reading teaching and put forward new affective reading teaching approaches. Most scholars claim that the method which applies context to reading teaching is widely accepted. The paper will elaborate the approaches in detail. As mentioned above, context theory is divided into linguistic context and non-linguistic context. In order to learn reading well, many linguists apply context to reading teaching. The author discusses the linguistic context and non-linguistic context in the application of English reading teaching. Linguistic context refers to the internal environment in which language occurs (van Dijk, 2009 [6]). Teachers should let students know the importance of context theory and what linguistic context is.

Mastering more words is the basis to learn English well. Therefore, teachers' current task is to teach students to infer the meaning of new vocabularies under the guidance of linguistic context, rather than rely on the dictionary because inferring means discovering the meaning of unknown elements by using syntactic, logical and cultural clues to discover the meaning of unknown elements (Grellet, 2000 [7]; Johnson, 2013 [8]).

There are many polysemous words or sentences in English, which have no specific meaning isolated from context. Because of ambiguity, students cannot know the accurate meaning of words or sentences, even the real purpose of what the article expresses. In order to eliminate the ambiguity and master the correct meaning of words or sentences, students should understand the meaning of words connecting with specific context under the guidance of linguistic context. Teachers need to teach students how to eliminate ambiguity through applying context to their reading. It can be seen that it is useful for students to improve their reading ability by using prediction. Therefore, teachers should teach students the method in English reading based on linguistic context.

As mentioned above, it shows that applying context theory to English reading teaching is helpful for college students. The purpose of using this method is to let students realize the importance of context theory and improve students' reading capacity. For the current situation of English reading teaching in China, teachers should attempt to apply context theory to English reading teaching in college.

\section{Research Methodology and Tools}

Apart from traditional reading teaching method, this paper mainly discusses the application of context theory to English reading teaching in college. The purpose of the experiment is to test whether the application of context theory to English reading teaching is more effective than the traditional one. 
The research project was conducted in a university in Northern China from March to June, 2015. Two parallel classes of sophomores with non-English majors were chosen as research participants. Fifty-eight sophomore students in the experimental class were taught by using the context-based reading teaching method, while fifty-seven sophomore students in the control class were taught by the traditional teaching method continuously. Research instruments in this study included questionnaires, tests and interviews. All the data were analyzed using qualitative and quantitative techniques.

In the process of reading teaching, the two classes were taught with the same teacher, the same teaching material, the same teaching time. The only difference was to adopt different teaching methods in the two classes. The control class was taught by using traditional reading teaching method, while the experimental class focused on the teaching method under the guidance of the context theory.

The tests were conducted to measure the students' English reading comprehension in the two classes, which consisted of pre-test and post-test. As this study is experimental research, pre-test and post-test are indispensable to be designed for the control and experimental class (Cohen, Manion \& Morrison, 2011) [9]. In order to ensure the validity and reliability of the tests, the author adopted CET-4 (College English Test Band 4 in China) reading comprehension as the pre- and post-tests. Pre-test were conducted before the experiment, and the students from Control Class and Experimental Class take the reading comprehension test simultaneously. To guarantee the validity of the test, the students are informed that the scores will be part of their usual performances, That is, they need not attach extra importance to the test. Time is limited to 60 minutes.

Teaching procedures in Control Class consist of 3 stages: (1) pre-reading, in which students are required to memorize vocabularies in the form of lists of isolated words; (2) while-reading, in which students are demanded to read the reading material and underlie the difficult language points, which are to be explained by the teacher using some concrete teaching methods; (3) post-reading, during which the students focus on learning grammatical knowledge and attempting to translate some sentences in the passage.

Teaching procedures in Experimental Class also subsume 3 stages, namely pre-reading, while-reading and post-reading. However, to each stage more learning tasks are added to enforce the content of applying context tenet in English reading instruction. For example, for pre-reading, the author designed some reading tasks to input or activate. In while-reading, students are taught to learn dealing with linguistic context, analyze situational context, and predicting genre type. For the purpose of achieving this goal, skimming and scanning reading techniques are employed in while-reading, and most important of all, students should learn to master language knowledge and reading skills by using context theory. In post-reading stage, students are cultivated the awareness of finding out cultural features involved in the text.

The post-test was conducted after four months' training, the purpose of which is to demonstrate the effectiveness of the application of context teaching method. After the students are informed that their testing results will be counted as part of their usual performances, they are expected to treat the test seriously and thus guarantee the validity of the test.

In order to know students' attitude towards reading strategy and other personal information on the context-based reading teaching, the author designed an interview after the experiment at the end of the semester. The interview was carried out in the experimental class. The purpose of the interview was to investigate further whether this approach could change students' attitude and cultivate reading strategy under the guidance of context theory.

\section{Results and Discussion}

This section mainly discusses the data analysis and discussion which are collected from the questionnaire, pre-test, post-test and the interview.

Before experiment, the students' attitude towards reading skills in the two classes were investigated, showing both classes are similar to each other. Also, it can be seen that the current situation of the students' using reading strategy are at the same level before the experiment. Table 1 
indicates that statistics of the pre-questionnaire and the post-questionnaire in Experimental Class. Both pre- and post-questionnaire are the same one so that the students' perceptions toward reading skills and strategies could be compared. The students were required to choose one answer to indicate the extent to which they either agreed or disagreed with a statement: (1) strongly disagree, (2) disagree, (3) agree, and (4) strongly agree. There were 10 statements in total.

Based on the analysis above, the students' attitudes towards reading in EC undergo an obvious change after the experiment. It shows that the new reading teaching method is helpful for students' reading learning. Based on the comparison between the pre-questionnaire and post-questionnaire in EC, it is found that students' employment of reading strategy has witnessed an improvement. In summary, the context-based English reading teaching method has great influence on students' English reading learning.

Table 1. Statistics of pre-questionnaire and post-questionnaire in EC ( $\mathrm{n}=58)$

\begin{tabular}{|c|c|c|c|c|c|}
\hline Questions & $\begin{array}{c}\text { Questio- } \\
\text { nnaire }\end{array}$ & $\begin{array}{l}\text { strongly } \\
\text { agree }\end{array}$ & agree & $\begin{array}{l}\text { disa- } \\
\text { gree }\end{array}$ & $\begin{array}{l}\text { strongly } \\
\text { disagree }\end{array}$ \\
\hline \multirow{2}{*}{$\begin{array}{l}\text { (1) I spend much time on understanding } \\
\text { English articles. }\end{array}$} & Pre- & $66 \%$ & $26 \%$ & $8 \%$ & 0 \\
\hline & Post- & $15 \%$ & $18 \%$ & $23 \%$ & $44 \%$ \\
\hline \multirow{2}{*}{ (2) English reading is difficult to me. } & & $61 \%$ & $33 \%$ & $6 \%$ & 0 \\
\hline & Post- & $13 \%$ & $19 \%$ & $27 \%$ & $41 \%$ \\
\hline \multirow{2}{*}{$\begin{array}{l}\text { (3) I can predict the content according to the } \\
\text { title of an article. }\end{array}$} & & $14 \%$ & $21 \%$ & $32 \%$ & $33 \%$ \\
\hline & Pos & $43 \%$ & $36 \%$ & $17 \%$ & $4 \%$ \\
\hline \multirow{2}{*}{$\begin{array}{l}\text { (4) I can guess the meaning of new words } \\
\text { according to context. }\end{array}$} & & $12 \%$ & $21 \%$ & $40 \%$ & $27 \%$ \\
\hline & Post- & $51 \%$ & $25 \%$ & $19 \%$ & $5 \%$ \\
\hline \multirow{2}{*}{$\begin{array}{l}\text { (5) I can eliminate ambiguity of words } \\
\text { according to context. }\end{array}$} & & $9 \%$ & $16 \%$ & $45 \%$ & $30 \%$ \\
\hline & Post- & $39 \%$ & $31 \%$ & $18 \%$ & $12 \%$ \\
\hline \multirow{2}{*}{$\begin{array}{l}\text { (6) I can find the key sentences in the texts } \\
\text { through skimming and understand the main } \\
\text { ideas of texts. }\end{array}$} & & $18 \%$ & $16 \%$ & $30 \%$ & $36 \%$ \\
\hline & Post- & $38 \%$ & $30 \%$ & $22 \%$ & $10 \%$ \\
\hline \multirow{2}{*}{$\begin{array}{l}\text { (7) I can locate the specific information in texts } \\
\text { through skipping. }\end{array}$} & Pre & $20 \%$ & $19 \%$ & $35 \%$ & $26 \%$ \\
\hline & Pos & $52 \%$ & $28 \%$ & $15 \%$ & $5 \%$ \\
\hline \multirow{2}{*}{$\begin{array}{l}\text { (8) I can understand the relevant background } \\
\text { knowledge of the article before reading. }\end{array}$} & Pre- & $10 \%$ & $15 \%$ & $18 \%$ & $57 \%$ \\
\hline & & $61 \%$ & $21 \%$ & $11 \%$ & $7 \%$ \\
\hline \multirow{2}{*}{$\begin{array}{l}\text { (9) My English reading efficiency is very high } \\
\text { in the reading process. }\end{array}$} & Pre- & $9 \%$ & $16 \%$ & $45 \%$ & $30 \%$ \\
\hline & Post- & $56 \%$ & $34 \%$ & $10 \%$ & 0 \\
\hline \multirow{2}{*}{$\begin{array}{l}\text { (10) I have confidence in improving my } \\
\text { English reading ability. }\end{array}$} & Pre- & $16 \%$ & $19 \%$ & $35 \%$ & $30 \%$ \\
\hline & Post- & $60 \%$ & $25 \%$ & $15 \%$ & 0 \\
\hline
\end{tabular}

Note: (1). ( $n=58)$ means that 58 students answered the questionnaire correctly, and their answers are summarized here. ' $n$ ' represents 'number'. (2). EC=Experiment class; $C C=$ Control class

Table 2 indicates that the mean score of the pre-test and post-test in EC and CC. The mean score of the pre-test in CC and EC are very similar, showing that there is no much difference between EC and CC. However, there is a significant difference in EC before and after the experiment. The context-based reading teaching approach can improve the students' reading performance in EC effectively. 
Table 2. Statistics for scores of pre- and post-test in EC and CC

\begin{tabular}{c|c|c|c|c|c|c|c|c}
\hline & Class & $\mathrm{N}$ & Mean & & Class & $\mathrm{N}$ & Mean & $\begin{array}{c}\text { Increased by (\%), in } \\
\text { comparison with pre-test }\end{array}$ \\
\hline \multirow{3}{*}{ Pre-test } & $\mathrm{EC}$ & 58 & 47.4 & \multirow{2}{*}{ Post-test } & EC & 58 & 66.8 & 19.4 \\
\cline { 2 - 8 } & $\mathrm{CC}$ & 57 & 48.5 & & $\mathrm{CC}$ & 57 & 53.7 & $5.2 \%$ \\
\hline
\end{tabular}

The interview aims to investigate further whether the context-based reading teaching approach can change students' attitude to reading and cultivate their reading strategy. The author designs the interview for the students in the experimental class after the experiment. According to the analysis of the interview, it shows that the students' attitude towards reading skills have changed and their reading strategy have been improved obviously after the experiment. The new reading teaching method has an effective influence on students' attitude towards reading and reading strategy.

\section{Conclusion}

The paper demonstrates that the context-based reading teaching method has a positive and efficient influence on English reading teaching. Through the guidance of context theory, the students' reading scores have been greatly improved. In other words, the context-based reading teaching approach is more efficient than the traditional one. And most important of all, students have learnt to form a more adaptive mode of reading, which is helpful for them to infer the meanings of new words, to eliminate ambiguities of some expressions, and to anticipate reading content. Additionally, it is found that students' reading interests have been greatly aroused with the introduction of context theory, and good reading skills and habits have been formed and cultivated by using linguistic and non-linguistic contexts in the process of reading.

According to the analysis and discussion in the previous section, some implications of the research can be shown in the following. First, teachers should emphasize on teaching students how to apply context theory to deal with English reading problems. Second, students should pay attention to cultivating their interest in English reading in order to increase confidence in learning English reading. Third, students should be considered as the center in classroom teaching, while the teachers as guiders.

\section{Acknowledgement}

This paper has been sponsored by Liaoning Social Science Planning Fund Program (No. L12DYY026) of China.

\section{References}

[1] N. J. Anderson, "Reading instruction" In J. Richards \& A. Burns (Eds.), Cambridge Guide to Pedagogy and Practice in Language Teaching. Cambridge: Cambridge University Press, pp. 218-225, 2012.

[2] W. Grabe, F. L. Stoller, "Teaching and Researching Reading (2nd Edition)". New York: Routledge, pp. 62, 2013.

[3] M. A. K. Halliday, "Studies in Chinese Language," Vol. 8. London: Continuum, pp. 161, 2005.

[4] J. Lyons, "Linguistic Semantics: An Introduction,". Cambridge: Cambridge University Press, pp. 76, 1995.

[5] G. Brown, G. Yule, "Discourse Analysis," Beijing: Foreign Language Teaching and Research Press, pp. 101-106, 2008. 
[6] T. A. van Dijk, "Discourse and Context: A Sociocognitive Approach," Cambridge: Cambridge University Press, pp. 92, 2008.

[7] F. Grellet, "Developing Reading Skills," Cambridge: Cambridge University Press, pp. 43-48, 2000.

[8] K. Johnson, "An Introduction to Foreign Language Learning and Teaching (2nd Edition)," New York: Routledge, pp. 81-88, 2013.

[9] L. Cohen, L. Manion \& K. Morrison, "Research Methods in Education," London and New York: Routledge, pp. 124, 2011. 